\title{
Effect of water availability on the development of Paspalum virgatum $\mathbf{L}$.
}

\author{
${ }^{1}$ Paulo Cesar Laurindo Silva, ${ }^{1}$ Oscar Mitsuo Yamashita ${ }^{2}$, Ivone Vieira da Silva ${ }^{2}$, Adriano Maltezo da Rocha ${ }^{2}$, \\ Bruna Zonta de Brito ${ }^{2}$, Vanessa de Andrade Royo ${ }^{3}$, Keyla Laisa Araújo Saldanha ${ }^{3}$, Marco Antonio Camillo de \\ Carvalho $^{2}$
}

${ }^{1}$ Instituto Federal de Mato Grosso, IFMT, Campus Confresa - Av. Vilmar Fernandes, 300, Confresa, MT,. 78652-000, Brazil.

${ }^{2}$ Programa de Pós-Graduacão em Biodiversidade e Agroecossistemas Amazônicos, UNEMAT, Campus II - Avenida Perimetral Rogério Silva, 4930 - Jardim Flamboyant, Alta Floresta, MT. 78580-000, Brazil

${ }^{3}$ Programa de Pós-Graduação em Biotecnologia, Universidade Estadual de Montes Claros, UNIMONTES. Vila Mauriceia, Montes Claros, MG. 39401-089, Brazil.

Correspondence Author: Paulo Cesar Laurindo Silva., Instituto Federal de Mato Grosso, IFMT, Campus Confresa - Av. Vilmar Fernandes, 300, Confresa, MT, 78652-000, Brazil

E-mail:- paulo.silva@cfs.ifmt.edu.br

Received date: 15 September 2019, Accepted date: 12 December 2019, Online date: 31 December 2019

Copyright: (C) 2019 Paulo Cesar Laurindo Silva et al, This is an open-access article distributed under the terms of the Creative Commons Attribution License, which permits unrestricted use, distribution, and reproduction in any medium, provided the original author and source are credited.

\begin{abstract}
Paspalum virgatum (L.) is a monocotyledonous species considered to be an important weed. It is a difficult to control plant, as it has the same morphological, physiological and biochemical characteristics of plants cultivated for use as fodder. Due to the difficulty of control, this plant has caused damage in the pasture areas. In periods of lack of rainfall in the Amazon region, there is the possibility of adopting management practices. However, the behavior of $P$. virgatum under conditions of water stress is not known. The hypothesis is that, due to its characteristics, the species is tolerant to the lack or excess of water, which allows it to survive even after several months without water supply or also in rainy periods where there is water abundance, very common situations in the region. Amazon. The aim of this study was to evaluate the behavior of $P$. virgatum in situations of water stress (lack and excess of water). The experiment was carried out in a greenhouse. In a $3 \times 2$ factorial scheme, three water availability (water deficit, field capacity and flooding) were evaluated in two evaluation periods (28 and 56 days). Plants subjected to water deficit were lower than those under field capacity and flooding, presenting higher values for height, stem diameter, number of leaves and number of tillers. There was variation of response to the other variables when the plants were kept in the three different water conditions. However, no plants died, demonstrating rusticity and adaptation of the species to these conditions. The water deficit condition promoted higher values than the field capacity and flooding only for the chlorophyll content of the plants. Thus, it is concluded that $\boldsymbol{P}$. virgatum is less resistant to water deficit than to soil flooding; whereas water deficit causes a higher nitrogen concentration in P. virgatum shoot; Although the water deficit reduces the development of the species, it still showed high aggressiveness and recovery under water stress conditions. From this information, it is verified that waiting for the plant to wither due to lack or excess of water, or use of controlled floods will not promote satisfactory control of the species. Thus, it is necessary to develop management practices that consider this capacity of $P$. virgatum to survive both under and under water in the substrate where it develops, and can stay alive for long periods.
\end{abstract}

Keywords: Flood, Water deficit, Weed

\section{INTRODUCTION}

Paspalum virgatum L., commonly known as razor grass, is considered one of the most important invasive species of pasture in the Amazon, due to its aggressiveness, high multiplication capacity and competition with forages, especially in humid soils. $P$. virgatum is considered a difficult to control plant due to its morphological, physiological and biochemical similarity to forage grass, still in its early phase. Cattle graze it in forage lag situations, and its aggressiveness is widespread by horses because they appreciate their seeds (Silva et al., 2017; Andrade et al., 2012; Dias-Filho, 2007).

Knowledge of the developmental characteristics of the species under stress conditions may favor the development of more correct and efficient management strategies. Moreover, in the case of $P$. virgatum, due to its high aggressiveness, making 
chemical management difficult (Takeshita et al., 2018), any information about its development under different water conditions (excess or deficit) may allow the adoption of agricultural practices. at different times of the year.

Water deficit can significantly affect most plant species as it promotes stomatal closure, which is the primary regulating mechanism of plant water balance, causing a reduction in photosynthesis rate by decreasing $\mathrm{CO}_{2}$ entry into the plant, causing wilting. of the leaves. Restriction of water also reduces the respiration rate, growth and development of plants. Dry periods can cause early flowering and accelerated senescence. There is also a large-scale production of abscisic acid and ethylene, plant hormones that cause accelerated plant ageing (Pes and Arenhardt, 2015).

On the other hand, excess water, periods of flooding that last for many days, can lead species to death due to their difficulty in the roots to perform gas exchange, energy metabolism and even their physical support may be impaired (Rosa et al. al., 2015). Thus, excess water in the soil is also detrimental to plant growth and development, leading to reduced yields. The amount of water and air in the soil must be in balance for good plant development, as water and air occupy soil porosity at approximately 50\% of the total volume. As the soil is occupied by water, it decreases the amount of air, causing the soil to be soaked and no air present, which causes the roots to perform anaerobic respiration and, consequently, reduces root growth, decreases soil absorption. . water and nutrients (Pes and Arenhardt, 2015).

Thus, plant survival and development depend on changes and adaptations at the molecular, biochemical, morphological and physiological levels in order to ensure organism homeostasis, both under deficit and excess water conditions (Loreti et al., 2016; Araújo et al., 2019).

Studies on the ecological aspects of spontaneous plants are becoming increasingly important (Schneider et al., 2018), including the factors that govern plant physiology, biochemistry, and those that control seed germination, seedling emergence, and seedlings. ability to withstand extreme water conditions such as flooding and water deficit (Yamashita, 2010). Proper management of agroecosystems is essential to evaluate the dynamics of spontaneous plant communities, seeking knowledge of the interaction between these plants, crops and their impacts (Carvalho, 2011).

Seeking more excellent knowledge for the proper management of $P$. virgatum, aiming to reduce the environmental impact and preserve biodiversity, it is important to deepen the understanding about its degree of tolerance to water stress. In this context, the present research aimed to evaluate the behavior of $P$. virgatum in different water availability, field capacity, water deficit and flood.

\section{MATERIAL AND METHODS}

Paspalum virgatum seeds were collected in Alta Floresta - MT, in natural infestation areas in the city center in June 2017. Panicles of plants, whose color visually indicated maturation, were covered with a paper bag and gently shaken with lateral movement. Only the seeds that stood out were collected. This procedure was performed in at least 30 plants to ensure the genetic variability of the material collected in the region. Subsequently, these seeds were taken to the laboratory and subjected to precleaning and drying. Soon after, $P$. virgatum seeds were cleaned using an electric bench blower. The material was stored in paper bags and kept in a cold chamber until its use.

The soil was collected in the $0-0.20 \mathrm{~m}$ depth layer, in the forest area, which was used in the experimental units. This substrate was classified as Red Yellow Latosol (LVa). After collection, soil physical and chemical analyzes were performed. From the analysis information, the necessary calculations were performed for the correction and fertilization of the soil, to supply the possible nutrient deficiencies for the full development of the plants. For limestone and nutrient application, the soil was sieved and mixed with a large hoe, using $5.0 \mathrm{~g} \mathrm{dm}^{-3}$ dolomitic load, $2.54 \mathrm{~g} \mathrm{dm}^{-3}$ single superphosphate, $2.54 \mathrm{dm}^{-3}$ single phosphate, $0.089 \mathrm{~g}$ of urea $\mathrm{dm}^{-3}$ and $0.3 \mathrm{~g} \mathrm{dm}^{-3}$ of potassium chloride.

For plant reproduction, $P$. virgatum seeds were submitted to dormancy break with P.A sulfuric acid. The seeds were kept dipped in acid for six minutes. Then the seeds were washed under running water for 5 minutes (Silva et al., 2017). After dormancy broke, expanded 124-cell polyethylene trays were used and seeded, leaving the seedlings to develop until they could be transplanted into the pots. After transplantation, the seedlings were expected to be $15 \mathrm{~cm}$ long in the shoot. Immediately thereafter began the implementation of treatments that consisted of different water availability, since the plants were already established.

Each pot received a single plant, which was the experimental unit. Experimental units subjected to water deficit were irrigated only three times, providing the minimum amount for plant survival $(100 \mathrm{~mL}$ per pot $)$. Field capacity treatments were irrigated daily with the objective of keeping the experimental units always in this condition.

To determine the field capacity initially were filled with a dry substrate, five plastic containers (similar to those used in the experiment) perforated at the base and weighed on a digital scale. Shortly after that, each box received $2000 \mathrm{~mL}$ of water distributed throughout the substrate surface. These containers were placed over another unperforated container which was held suspended by a sieve. After one hour, the perforated container was weighed again and the volume of water drained was determined using a graduated beaker. From this weighing and the collected volume, it was determined the volume of water needed to reach the field capacity of the experimental units. This determination was made once a week to readjust the volume of water supplied to the experimental units as the plants grew. Plants subjected to flooding were kept in plastic trays with sufficient water volume so that, by saturation, the plants developed under conditions of excess water.

The experiment was conducted in a completely randomized design, in a 3 x 2 factorial scheme, with three water availability [water deficit (D), field capacity (C) and flooded (A)], two cutting times and five replications. for each treatment. Plants from season 1 (E1) were cut to $5 \mathrm{~cm}$ from the ground every 28 DAA (days after water application), while plants from season 2 (E2) were every $56 \mathrm{DAA}$, so at the time of the evaluations, there were young plants (E1) as they were cut more recently, and older plants (E2) that remained blunt for longer periods. 
For the variables height $(\mathrm{cm})$, stem diameter $(\mathrm{mm})$, number of leaves, chlorophyll content and number of tillers of the navalhão grass, monthly evaluations were performed, performing 4 evaluations (28, 56, 84 and 112 DAA), while Para The destructive variables The dry mass of leaves $(\mathrm{g})$ and leaf area $(\mathrm{cm} 2)$ occurred in two moments (56 and 112 DAA), and in these evaluations, the plants were cut at both moments (E1 and E2).

Plant growth was measured with a tape measure. For stem diameter, a digital calliper was used. The chlorophyll content index (determined indirectly by SPAD readings) on leaves near the apex (Icica) and leaves near the base (ICCfb), obtained from a fiveleaf sample per treatment, using the CCM- 200, Opti-Science. To determine the leaf area, the LICOR 3100C equipment was used. To obtain the dry mass of the leaves, the parts of $P$. virgatum were separated and placed in identified paper bags, then dried in an oven with forced air circulation at $65^{\circ} \mathrm{C}$ for 72 hours and weighed in a seminalitic scale with precision 0.01 grams.

The results were subjected to analysis of variance by the F test, the means were compared by Tukey test at $5 \%$ probability. The statistical software Sisvar (Ferreira, 2011) was used to perform the analyzes of this study.

\section{RESULTS AND DISCUSSION}

There was a differential behavior of $P$. virgatum submitted to different treatments. The answers were found in all studied variables. Time significantly affected plant height only at 56 and 112 DAA. The interaction between "water condition" and "season" was verified in the last two evaluations (84 and 112 DAA).

In the first two evaluations, the highest values were verified when the plants were kept under flood conditions and field capacity (Table 1). These treatments differed from the other, by the presence of water in the substrate, demonstrating that this species developed better in a water environment, even if in excess.

The literature reports that forage grasses are generally intolerant to flooding for extended periods, especially those marketed for cultivation and pasture formation (Valentim et al., 2000; Dias-Filho 2002). However, P. virgatum has been shown to be able to develop under these conditions. This adaptability may be linked to changes in plant behavior and even the biological, physical and chemical characteristics of the soil affected by excess water (Dias-Filho and Carvalho, 2000). Some research has related this adaptive capacity to three factors: stomatal conductance, liquid photosynthesis and alcoholic dehydrogenase (ADH) activity. Increasing these values may indicate species sensitivity to flooding. Baruch (1994a; 1994b) found that Brachiaria mutica and Echinochloa polystachya, typical wetland species, have similar stomatal conductance, net photosynthesis, and ADH activity between flooded and non-flooded plants.

At 84 DAA, plants from season 1, under flooding, presented higher height than plants from season 2. At the same evaluation date, when compared to water conditions, it was found that, under flooding, plants from season 1 presented height. Compared to those under water stress and field capacity. Plant season 2 behaved differently, in which CC and DH differed from each other and under flooding, resembling each other (Table 2).

At 112 DAA, plants from season 1 presented higher height under flood conditions, compared to field capacity and water deficit. Plants of the second season showed higher growth under field capacity conditions compared to the other conditions. And by comparing the ages of the plants (season 1 and 2), it looks like they looked like flooding conditions. Already CC and DH, the plants of season 2 were larger than those of season 1 .

In these two assessments, it was found that the flooding provided a condition of height increase in the plants of season 1. This increase was higher than the other conditions. The plants of the second season presented higher height under field capacity. Excess water may have favored season 1 plants at a stage of intense vegetative development and tillering. This condition may be related to the ability of this plant to adapt to flooding. Striker et al. (2010), studying Paspalum dilatatum, also found that these plants, in a flooded environment, had a higher crown than the others, without flooding.

Excessive water in the soil, causing flooding causes a reduction in gas exchange between the plant and its environment (Silva et al., 2009). This situation is defined as anoxia. This condition, if maintained for long periods of time, can cause extremely harmful effects to flood of intolerant species as it alters cellular metabolism, causing an immediate reduction in root respiration rate (Liao and Lin, 2001). Lack of oxygen causes a reduction in ATP production. This reduction affects cellular metabolism because it restricts the energy supply for plant growth when flood intolerant (Suralta and Yamauchi, 2008). However, the studied species tolerate anoxia, demonstrating its rusticity in adverse conditions.

According to Andrade et al (2012), P. virgatum species considered extremely rustic weeds and adapted to different environmental conditions, especially in moist soils. These plants probably developed an adaptive morphoanatomic response to this situation, especially the season 1 plants in intense vegetative development. One such response is the formation of aerenchyma and adventitious roots, which can capture and transport oxygen to submerged tissues (Armstrong et al., 1994). These aerenchyma, due to their larger intracellular spaces, offer reduced resistance to gas exchange between roots maintained in anaerobic environment and the shoot under aerobic conditions (Jackson and Armstrong, 2008).

Table 1: Average values for Paspalum virgatum height $(\mathrm{cm})$, stem diameter $(\mathrm{cm})$, number of sheets, chlorophyll content, number of leaves, dry leaf mass and leaf area subjected to different water conditions: A: flooded; CC: field capacity; DH: water deficit.

\begin{tabular}{|c|c|c|c|}
\hline Water Condition & \multicolumn{3}{|c|}{ Days after evaluation (DAA) } \\
\hline Height $(\mathrm{cm})$ & & $28 \mathrm{DAA}$ & 56 DAA \\
\hline $\mathrm{DH}$ & & $49.05 \mathrm{~b}$ & $64.95 \mathrm{~b}$ \\
\hline $\mathrm{A}$ & & $59.05 \mathrm{a}$ & $74.95 \mathrm{a}$ \\
\hline $\mathrm{CC}$ & & $59.55 \mathrm{a}$ & $74.30 \mathrm{a}$ \\
\hline Stem diameter $(\mathrm{cm})$ & & $28 \mathrm{DAA}$ & $84 \mathrm{DAA}$ \\
\hline
\end{tabular}




\begin{tabular}{|c|c|c|c|}
\hline DH & & $4.71 \mathrm{~b}$ & $5.16 \mathrm{~b}$ \\
\hline A & & $6.38 \mathrm{a}$ & $7.34 \mathrm{a}$ \\
\hline CC & & $6.52 \mathrm{a}$ & $7.15 \mathrm{a}$ \\
\hline Number of sheets & & 28 DAA & 84 DAA \\
\hline DH & & $14.90 \mathrm{~b}$ & $14.20 \mathrm{~b}$ \\
\hline A & & $17.50 \mathrm{a}$ & $24.75 \mathrm{a}$ \\
\hline CC & & $17.70 \mathrm{a}$ & $24.70 \mathrm{a}$ \\
\hline Chlorophyll content & & 28 DAA & 84 DAA \\
\hline DH & & $45.85 \mathrm{a}$ & $41.97 \mathrm{a}$ \\
\hline A & & $30.48 \mathrm{~b}$ & $35.13 \mathrm{~b}$ \\
\hline CC & 28 DAA & $31.29 \mathrm{~b}$ & $38.16 \mathrm{~b}$ \\
\hline Number of leaves & $3.70 \mathrm{~b}$ & $3.50 \mathrm{~b}$ & $112 \mathrm{DAA}$ \\
\hline DH & $6.70 \mathrm{a}$ & $5.80 \mathrm{a}$ & $17.50 \mathrm{~b}$ \\
\hline A & $5.80 \mathrm{a}$ & $5.40 \mathrm{ab}$ & $27.20 \mathrm{a}$ \\
\hline CC & & & $56.00 \mathrm{a}$ \\
\hline Dry leaf mass & & & $3.05 \mathrm{~b}$ \\
\hline DH & & & $3.97 \mathrm{a}$ \\
\hline A & & & $3.33 \mathrm{~b}$ \\
\hline CC & & & $56 \mathrm{DAA}$ \\
\hline Leaf area & & & $48.53 \mathrm{c}$ \\
\hline DH & & & $56.27 \mathrm{~b}$ \\
\hline A & & & $\mathrm{T}$ \\
\hline CC & & & \\
\hline
\end{tabular}

Means followed by the same letter in the column do not differ from each other by the Tukey test at $5 \%$ probability.

Grass cutting time influenced the height of $P$. virgatum plants, and at 28 DAA the plants were $10 \%$ shorter than at 56 DAA, indicating that even under adverse water conditions, the plants grew within 28 days (Table 3). This is a very aggressive invasive species that seeks to occupy the spaces intensely and quickly. Thus, this initial growth, characteristic of the species, should be considered during the elaboration of management strategies. Sistachs and León (1987) comment that P. virgatum seeds buried 7.5 $\mathrm{cm}$ deep could still emerge from the soil, demonstrating their potential to occupy areas even when the seeds are at great depths.

In addition, species management strategies recommended by research institutions in Brazil suggested clearing the area in the dry season (outside the rainy season) before pasture reform, since $P$. virgatum propagules are incredibly aggressive and may occupy the area again well before cultivation or other forage (Andrade et al., 2012). The results of the present study reinforce this recommendation, demonstrating intense initial vegetative development of the species.

Regarding the diameter of $P$. virgatum stem, it was found that at 28 DAA there was significance only for the water condition; at 56 and 112 DAA there was the interaction between water conditions and seasons; and at 84 DAA, only importance for water conditions and seasons, but in isolation. Comparing the seasons of the year, at 56 DAA, only in field capacity (CC) there was no difference in stem diameters between plants of season 1 and season 2. In the conditions of water deficit (DH) and flooded (A), plants more season 2 presented higher values for this variable (Table 2). At 112 DAA, larger diameters were measured in WC and A in HD, with no difference between stations.

This behavior, although occurring in $\mathrm{CC}$ and $\mathrm{DH}$, was more intense under flood conditions (A) at 56 and 112 DAA, indicating the response of the plants of season 1 to this situation, which resulted in less stem thickening. The lack of oxyg enation caused by flooding causes changes in the metabolism of most grass species, causing an immediate drop in root respiration (Braendle and Grawford, 1999). Thus, what caused the reduction in the stem diameter of plants in season 1 was the decrease in ATP production caused by lack of oxygen, which affected various aspects of cellular metabolism (Fukao and Bailey-Serres, 2004), restricting the supply of energy for growth of different parts of the plant, including the stem, thereby reducing its diameter (Sousa and Sodek, 2002).

Comparing the water conditions in each season, at 56 DAA it was found that the water deficiency caused a significant reduction in stem diameter. These results indicate that the plants of the 1st and 2nd seasons suffered the effect of lack of water, ranging from 30 to $37 \%$ thicker than the CC condition. This response was verified when the plants were less than two months old. Over time, the plants recovered and, at 112 DAA, the result was the opposite for the plants of the 1st season, whose diameter was $15 \%$ larger in DH compared to WC. The plants of season 2 did not differ from each other. In the evaluation of 28 and 84 DAA, the lack of water caused a reduction in stem diameter (Table 1). Lack of water has altered the distribution of photoassimilates, reducing the development of young plants as an adaptive strategy for this species, thus reducing water consumption and other photosynthesis byproducts, seeking to maintain their vitality at this critical time (Coutinho et al., 2015). Stretching and thickening of the stem, leaves and roots are physiological processes sensitive to soil water availability and are drastically reduced even before photosynthesis and cell division processes. This is due to reduced cell turgor, which directly affects cell division and expansion processes (Turner, 1997; Yordanov et al., 2003).

After this period, stem thickening becomes a physiological necessity to maintain and support the plant structure and condition it to compete with the environment, raising the leaves to higher canopy levels, favoring intense physiological activity. (Wright et al., 1983). 
Regarding the number of leaves, there was the sign for the water condition at 28, 84 and 112 DAA and in this same evaluation (112 DAA), there was also a difference between the seasons. Lack of water interfered with the emission of $P$. virgatum leaves, significantly reducing its number in all evaluations except at 56 DAA (Table 1).

Thus, it is clear that the water deficit prevented the emission of new leaves by $P$. virgatum plants, because, according to Ludlow and $\mathrm{Ng}$ (1977), this effect occurs as a function of a genetically determined rhythm. However, this rate is significantly influenced by luminosity, temperature and water availability.

Table 2: The significant interaction between water condition and harvesting time (Season) for Paspalum virgatum height (cm), stem diameter, Chlorophyll content, Dry leaf mass and Foliar area. A: flooded; CC: field capacity; DH: water deficit. DAA: Day After evaluation

\begin{tabular}{|c|c|c|c|c|}
\hline \multirow{2}{*}{ Water Condition } & \multicolumn{2}{|c|}{84 DAA } & \multicolumn{2}{|c|}{ 112 DAA } \\
\hline & Season 1 & Season 2 & Season 1 & Season 2 \\
\hline \multicolumn{5}{|c|}{ Plant height } \\
\hline $\mathrm{DH}$ & $56.40 \mathrm{Ab}$ & $59.10 \mathrm{Ab}$ & $66.90 \mathrm{Bb}$ & $73.50 \mathrm{Ab}$ \\
\hline $\mathrm{A}$ & $74.50 \mathrm{Aa}$ & $64.38 \mathrm{Bab}$ & $76.12 \mathrm{Aa}$ & $74.30 \mathrm{Ab}$ \\
\hline $\mathrm{CC}$ & $64.70 \mathrm{Ab}$ & $71.28 \mathrm{Aa}$ & $63.60 \mathrm{Bb}$ & $84.50 \mathrm{Aa}$ \\
\hline DMS (line) & & & & 8.04 \\
\hline DMS (column) & & & & 9.74 \\
\hline \multicolumn{5}{|c|}{ Stem Diameter } \\
\hline & \multicolumn{2}{|c|}{56 DAA } & \multicolumn{2}{|c|}{112 DAA } \\
\hline $\mathrm{DH}$ & $5.18 \mathrm{Bc}$ & $6.04 \mathrm{Ab}$ & $7.11 \mathrm{Aa}$ & $6.86 \mathrm{Aa}$ \\
\hline $\mathrm{A}$ & $7.33 \mathrm{Bb}$ & $9.11 \mathrm{Aa}$ & $5.93 \mathrm{Bb}$ & $7.36 \mathrm{Aa}$ \\
\hline $\mathrm{CC}$ & $8.26 \mathrm{Aa}$ & $8.67 \mathrm{Aa}$ & $6.00 \mathrm{Bb}$ & $7.57 \mathrm{Aa}$ \\
\hline DMS (line) & & & & 0.56 \\
\hline DMS (column) & & & & 0.85 \\
\hline \multicolumn{5}{|c|}{ Chlorophyll content } \\
\hline & \multicolumn{2}{|c|}{56 DAA } & \multicolumn{2}{|c|}{ 112 DAA } \\
\hline $\mathrm{DH}$ & $48.74 \mathrm{Aa}$ & $46.30 \mathrm{Aa}$ & $36.84 \mathrm{Aa}$ & $38.40 \mathrm{Aa}$ \\
\hline $\mathrm{A}$ & $31.52 \mathrm{Ab}$ & $21.94 \mathrm{Bb}$ & $31.82 \mathrm{Ab}$ & $23.06 \mathrm{Bb}$ \\
\hline $\mathrm{CC}$ & $33.34 \mathrm{Ab}$ & $22.68 \mathrm{Bb}$ & $34.96 \mathrm{Aab}$ & $23.06 \mathrm{Bb}$ \\
\hline DMS (line) & & & & 5.14 \\
\hline DMS (column) & & & & 4.41 \\
\hline \multicolumn{5}{|c|}{ Dry leaf mass } \\
\hline & & & \multicolumn{2}{|c|}{112 DAA } \\
\hline $\mathrm{DH}$ & & & $3.34 \mathrm{Aa}$ & $3.76 \mathrm{Ab}$ \\
\hline $\mathrm{A}$ & & & $2.90 \mathrm{Ba}$ & $7.67 \mathrm{Aa}$ \\
\hline $\mathrm{CC}$ & & & $2.53 \mathrm{Ba}$ & $7.83 \mathrm{Aa}$ \\
\hline DMS (line) & & & & 1.40 \\
\hline DMS (column) & & & & 1.45 \\
\hline \multicolumn{5}{|c|}{ Foliar area } \\
\hline & & & \multicolumn{2}{|c|}{112 DAA } \\
\hline $\mathrm{DH}$ & & & $40.20 \mathrm{Aa}$ & $45.71 \mathrm{Ab}$ \\
\hline $\mathrm{A}$ & & & $44.88 \mathrm{Ba}$ & $62.03 \mathrm{Aa}$ \\
\hline $\mathrm{CC}$ & & & $40.85 \mathrm{Ba}$ & $55.71 \mathrm{Aa}$ \\
\hline DMS (line) & & & & 8.17 \\
\hline DMS (column) & & & & 7.12 \\
\hline
\end{tabular}

Means followed by the same letter, uppercase in the rows, within each DAA (days after the water condition) and lowercase in the columns, do not differ from each other by the Tukey test at $5 \%$ probability.

Water relations are directly affected by the reduced availability of water in the soil. It also interferes with the physiology and morphology of forage plants. The lack of water available to the plant can cause stress that, depending on the magnitude, severely limiting species development and leading to death (Mattos et al., 2005). In the present study, the low available water caused intense plant dehydration and, as a result, accelerated the plant's senescence process, compromising plant growth by reducing leaf expansion and photosynthesis rates (Benett and Sullivan, 1981), the emergence of new leaves (Van Loo, 1992).

In a study with corn plants, Bonfim-Silva et al. (2011) report that there was less production of leaves when less water availability. This makes it possible to infer that this species has low drought tolerance in its initial development. However, the navalhão grass, studied in this work, although it was verified that the plants under water deficit presented inferiority compared to those of field capacity and flood, could withstand such stress.

Water restriction in buffelgrass also reduced leaf appearance, reducing leaf emission by up to 55\%, increasing irrigation shifts from 2 to 10 days without irrigation (Coutinho et al., 2015). Kroth (2013) observed a reduction in the number of leaves under flooded soil conditions and water deficit for Piatã and Xaraés cultivars and, in the case of Marandu cultivar, as in P. virgatum, the 
number of leaves in flooded soil was not different in the field capacity condition, although it was impaired in the water deficit condition.

$P$. virgatum cutting time influenced leaf number only in the 112 DAA evaluation. Plants cut every 56 days outnumber those cut every 24 days (Table 3). Certain moments of the plants when, after their action (in the absence and excess), caused a reduction in the number of leaves of the plants of season 1, resulting in almost $25 \%$ less leaf area for light energy capture and, consequently, energy production. to the plants. These results justify those reported by Benett and Sullivan (1981) and Van Loo (1992), cited above.

The chlorophyll index is indirectly determined by SPAD readings and is related to the nutritional assessment of plant nitrogen. From the data of this work, it can be deduced that the water condition influenced the amount of nitrogen in $P$. virgatum leaves (Costa et al., 2008; Lima et al., 2007). The green color index, or chlorophyll content, determined on plants during the experiment, demonstrates that there was an effect of water condition on all season evaluations at 56 and 112 DAA and on the interaction between the two factors at 112 DAA. .

Analyzing the green present in the leaves at 56 and 112 DAA, it was verified that the plants of season 1 presented higher index, except in the water deficit condition. The turgidity and the presence of sufficient water for the plants conditioned this response, allowing the plants of season 1 to fully develop. However, plants that developed underwater conditions apparently did not look good, but had green values above those under flood conditions and field capacity.

At 56 and 112 DAA, plants of season 1, under flood and field capacity, presented higher chlorophyll content than those of station 2. In the evaluation at 56 DAA, comparing the water conditions, it can be observed that the plants In water the deficit of both seasons presented higher chlorophyll content than flooding and field capacity. At 112 DAA, season 1 plants with water deficit showed higher chlorophyll content than flooded ones but did not differ from plants in field capacity. Plants of the second season with water deficit presented higher chlorophyll content than those of flood and field capacity (Table 2).

Similar to what happened with navalhão grass, Santos et al. (2013) evaluating the influence of water stress on Brachiaria brizantha cultivars, observed that the highest values of SPAD readings were found in the lowest water availability, $25 \%$ of field capacity. Like $P$. virgatum, Cunha et al. (2012) observed an increase in nitrogen content of the lemongrass (Cymbopogon citratus) shoot in plants with lower water availability, comparing the dry season with the rainy season.

Bonfim-Silva et al. (2011) and Torres Netto et al. (2005), in studies with SPAD readings, stated that there is no interaction between factors, grasses and water availability, and there was no difference between grasses (corn, sorghum and millet), with only difference between water availability and Higher chlorophyll content was observed in plants subject to water availability of $60 \%$ of field capacity.

In evaluations at 28 and 84 DAA, plants with water deficit presented higher chlorophyll content than plants maintained in field capacity and flooding (Table 1). The number of naval tillers showed significant variation in isolation for the "water condition" factor only at 84 and 112 DAA. The water deficit caused a reduction in the number of plant tillers. This reduction was verified only from 84 DAA. In the 112 DAA evaluation, despite the lower number of tillers, plants with water deficit did not differ significantly from those in field capacity (Table 1).

This water stress occurred because the rate of perspiration exceeded the rate of absorption and transport of water in plants (Berkowitz, 1998). The roots of P. virgatum, under this condition, acted as sensors of the lack of water in the soil, being later detected by the protective cells of the stomata, until before they felt some water deficit in the leaves, due to the alteration in the abscisic acid concentration. This change in concentration is interpreted as a chemical signal sent to the aerial part of the plant, resulting in lower tillers production (Salah and Tadieu, 1997), a fact observed in the present study.

Reduced soil water availability can have many negative effects on the plant, such as dehydration, increased plant senescence, reduced growth, and impaired growth and tillering, as it reduces photosynthesis and leaf expansion rates (Ludlow and Ng. 1976; Benett and Sullivan, 1981). grass species (Mattos et al., 2005).

The negative effect of water scarcity on this plant characteristic, verified in the present study, was also verified in other researches involving different grass species, methodologies and cultivation conditions (Ludlow and Ng, 1976; Buldgen and François, 1998; Mattos et al., 2005)

Results similar to $P$. virgatum were verified by Kroth (2013), who reported a reduction in the number of tillers of cultivar marandu with water deficit, and the plants in flooded soil and field capacity did not differ, and it can be stated that both The grasses are sensitive to water deficit and showed flood resistance. According to Coutinho et al. (2015), the number of buffelgrass tillers was reduced with decreasing water availability, from 9.7 to 1.2 tillers per pot. $P$. virgatum, although performing better under flood conditions and field capacity, was not reduced as buffel grass. Santos et al. (2011) report that there was a reduction in the number of elephant grass tillers, which is one of the main effects caused by water stress, and can be considered the reason for the low survival of this species in the semiarid region of northeastern Brazil. P. virgatum, in turn, has high resistance and even in water stress differs little from those under normal water conditions. Araújo et al. (2008) identified that the water restriction of less than $25 \%$ of soil water, regardless of the initial period (sowing, germination or tillering), reduced the number of marandu grass tillers. Similar results were found in this study where there was a significant difference only at 84 and 112 DAA, considering that, although rare, the plants emitted new tillers. This variable had a significant effect only on factors 56 and 112 DAA. There was also a significant interaction between water conditions and time at 112 DAA.

When comparing the two seasons, plants from season 1 had lower dry mass than season 2 plants in the field and flood capacity (Table 2). Underwater scarcity, the dried masses were similar, remaining close to $3.5 \mathrm{~g}$ per plant.

When comparing the water conditions, it was found that the lack of water compromised the leaf dry mass production only in plants with 60 days of water deficit, reducing the weight by more than $50 \%$ compared to the other conditions. The plants of season 1 were similar, but the values ranged from 2.53 to $3.34 \mathrm{~g}$, being much smaller than those of plants of the second season under field capacity and flood conditions. 
These results reinforce the importance of water for the development of $P$. virgatum plants because, with severe water scarcity, as was the case of the study, drastically reduced leaf dry mass production. The negative effect of water deficiency also harmed other grasses, such as elephant grass Napier (Andrade et al., 2005), marandu (Araújo et al., 2008; Rosa et al., 2015), pennisetum (Santos et al., 2011; Kroth et al., 2015).

The dry mass of marandu grass was significantly affected when subjected to water deficit, but soil water level negatively affected the final dry mass production of leaves, stems and roots, producing less when the water deficit was equivalent $25 \%$ of field capacity (Araujo et al., 2008). The highest leaf dry mass values at 56 DAA were observed in flooded plants. Plants did not differ significantly in field capacity and water deficit (Table 1).

One of the first reactions of plants to water scarcity is stomatal closure. This promotes the reduction of photosynthetic activity, reduction or arrest of growth and respiratory rate, which has a significant reduction (Pasin et al., 1991), which may have occurred with $P$. virgatum plants.

This behavior can be considered beneficial for the plants of this and other grass species, as it promotes greater energy storage in this water deficit condition, aiming to maintain its vitality until this change is circumvented when there is the regularization of water supply (Santos et al., 2011).

The accumulated dry mass of plants from season 1 was half that accumulated from plants from season 2 (Table 3).

Table 3: Average values height $(\mathrm{cm})$, number of leaves and dry leaf mass of Paspalum virgatum at both cutting seasons.

\begin{tabular}{|c|c|c|c|}
\hline \multirow{2}{*}{ Season } & Plant height $(\mathbf{c m})$ & Number of leaves & Dry leaf mass \\
\cline { 2 - 4 } & 56 DAA & 112 DAA & 56 DAA \\
\hline Season 1 & $67,43 \mathrm{~b}$ & $20,93 \mathrm{~b}$ & $2,83 \mathrm{~b}$ \\
\hline Season 2 & $75,37 \mathrm{a}$ & $27,53 \mathrm{a}$ & $4,08 \mathrm{a}$ \\
\hline DMS Tukey 5\% & 3,55 & 4,58 & 0,36 \\
\hline
\end{tabular}

Means followed by the same letter in the column do not differ from each other by the Tukey test at 5\% probability.

These results demonstrate that environmental changes, in this case, the water supply, can interfere with plant characteristics. According to Fischer and Silva (2001), besides the availability of water, the morphogenic characteristics of grassy plants can be influenced by temperature, despite being genetically determined.

These morphogenic variables, when combined, can determine the dynamics of tissue flow and the main structural characteristics of grasses such as tillers density, number of leaves per tillers and leaf size (Chapman and Lemaire, 1993). These variables can, when reduced, alter leaf dry mass accumulation, as verified in the present study. As for leaf area, there were differences in water availability at 56 and 112 DAA. However, in the assessment performed at 110 DAA, the interaction between the factors and 'weather' and 'water condition' were also verified.

Plants can develop mechanisms of adaptation to lack of water, such as cell wall thickening (Neumann, 1995), reduced osmotic potential (Barker et al., 1993), smaller leaf production (Klar et al., 1978), closure stomata (Chaves, 1991), increased root density and depth (Kano et al., 1999) and reduced leaf area (Rosenthal et al., 1987). However, leaf area reduction and stomata closure are the most limiting mechanisms for grass development, since they cause a significant reduction in the light interception and $\mathrm{CO}_{2}$ absorption capacity (Mattos et al., 2005).

Water deficit can have detrimental effects on the development of plants of different intensities. This is due to the reduction in leaf area, impairing the expansion and water potential of the leaves during the period when this stress occurs and the recovery after the return to water supply for these plants (Ludlow and $\mathrm{Ng}, 1977$; Mattos et al. , 2005).

As for the leaf area, season 1 did not cause any difference in water conditions. In the second season, it was observed that the plants under the water deficit condition were lower than the flood and field capacity. Comparing the two evaluation periods, it can be verified that the plants of the second season, in the condition of excess water and also of field capacity were superior to those of the first season. The plants that presented water deficit did not differ in any of the seasons (Table 2). According to Taiz and Zeiger (2009), the most common response of plants to water deficit is the reduction of leaf area, stomatal closure, acceleration of senescence and leaf abscission.

Comparing the water conditions, only in the absence of water, there were smaller leaf dimensions in relation to CC and A in the plants of season 2. Plants can develop mechanisms of adaptation to lack of water, such as cell wall thickening (Neumann, 1995), reduced osmotic potential (Barker et al., 1993), smaller leaf production (Klar et al., 1978), closure stomata (Chaves, 1991), increased root density and depth (Kano et al., 1999) and reduced leaf area (Rosenthal et al., 1987). However, leaf area reduction and stomatal closure are mechanisms that most limit the development of these grasses, since they cause significant reduction in the light interception and $\mathrm{CO}_{2}$ absorption capacity (Mattos et al., 2005). In the case of the present study, P. virgatum behaved in order to verify the reduction in leaf area, since the stomata were not analyzed.

At 56 DAA, lack of water significantly interfered with leaf development, reducing leaf size by at least 68\% (Table 1).

The result obtained by Rosa et al. (2015) was similar to P. virgatum in the 56 DAA assessment, where the leaf area of the plants kept in flood was smaller than the field capacity.

The intensity with which water deficit negatively affects plant development due to reduction in leaf area depends on the relationship between the rate of expansion and leaf water potential during stress and recovery after the return to water supply in these areas. (Ludlow and $\mathrm{Ng}$, 1977; Mattos et al., 2005), justifying this reduction, verified in the plants of the present study. 
Water deficit causes the highest concentration of nitrogen in Paspalum virgatum shoots. P. virgatum is more resistant to soil flooding than to water deficit. After the cutting period, $P$. virgatum recovers rapidly.

\section{ACKNOWLEDGEMENT}

The authors thank the Federal Institute of Mato Grosso, Campus de Confresa, for authorizing the first author to carry out the study and for funding this publication.

\section{FUNDING INFORMATION}

'Not applicable' for that section.

\section{CONFLICT OF INTEREST}

Authors declare no conflict of interest.

\section{REFERENCES}

Andrade, A.C., D.M. Fonseca, R.D. Lopes, D. Júnior Birth, P.R. Cecon, D.S. Queiroz, D.H. Pereira and S.T. Reis, 2005. Morphogenic and structural characteristics of fertilized and irrigated 'Napier' elephant grass. Science and Agrotechnology 29(1):150-159. http://dx.doi.org/10.1590/S1413-70542005000100019.

Andrade, C.M.S. J.R.A. Fontes, T.K. Oliveira and H.E. Farinatti, 2012. Pasture reforming with high razor grass (Paspalum virgatum) infestation. Rio Branco: Embrapa Acre, 14p.

Araujo, C.P., E.V. Amorim, V.L. Souza, F.Z. Bertolde, I.C. Santos and P.A.O. Mangabeira, 2019. Lead toxicity and soil flooding: survival mechanisms used by plants. Pindorama 9(9):81-101.

Araujo, L.C., P.M. Santos, F.C. Mendonça and G.B. Mourão, 2008. Evaluation of marandu grass under water deficit in a greenhouse during the establishment period. 45th Annual Meeting of the Brazilian Society of Zootechnics. Lavras, MG UFLA.

Armstrong, W., R. Brandle and M.B. Jackson, 1994. Mechanisms of flood tolerance in plants. Netherlands Botanical Act 43(4):307-358.

Barker, D.J. C.Y. Sullivan and L.E. Moser, 1993. Water deficit effects on osmotic potential, cell wall elasticity, and proline in five forage grasses. Crop Science 85(2):270-275.

Baruch, Z., 1994a. Responses to drought and flooding in tropical forages grasses. I. Biomass allocation, leaf growth and mineral nutrients. Plant and Soil, 164:87-96.

Baruch, Z., 1994b. Responses to drought and flooding in tropical forages grasses. II. Leaf water potential, photosynthesis rate and alcohol dehydrogenase activity. Plant and Soil, 164:96-107, 1994b.

Bennett, J.M. and C.Y. Sullivan, 1981. Effect of water stress preconditioning on net photosynthetic rate of grain sorghum. Photosynthetic 15(3):330-337.

Berkowitz, G.A., 1998. Water and salt stress. In: Raghavendra, A.S. (Ed.). Photosynthesis: comprehensive treatise. Cambridge: Cambridge University. 226-237p.

Bonfim-Silva, E.M., T.J.A. Silva, C.E.A. Cabral, B.E. Kroth and D. Rezende, 2011. Initial development of grasses subjected to water stress. Caatinga 24(2):180-186.

Braendle, R and R.M.M. Crawford, 1999. Plants as amphibians. Perspectives in Plant Ecology, Evolution and Systematics, 2(1): 56-78. https://doi.org/10.1078/1433-8319-00065

Buldgen, A. and J. François, 1998. Physiological reactions to imposed water deficit by Andropogon gayanus cv. bisquamulatus and Cenchrus ciliaris cv. biloela in mixed fodder crop. Journal of Agricultural Science 131(1):p.31-38. https://doi.org/10.1017/S0021859698005462

Carvalho, L.B., 2011. Ecological studies of weeds in agroecosystems. Edited by the author: Jaboticabal, 58p.

Chapman, D.F. and G. Lemaire, 1993. Morphogenetic and structural determinants of plant regrowth after defoliation. In: Baker, M.J. (Ed.). Grasslands for our world. Wellington: SIR Publishing. 55-64p.

Chaves, M.M., 1991. Effects of water deficits on carbon assimilation. Journal of Experimental Botany 42(234):1-16. https://doi.org/10.1093/jxb/42.1.1

Costa, K.A.P., V. Faquin, I.P. Oliveira, J.L. Araújo and R.B. Rodrigues, 2008. Doses and sources of nitrogen in marandu grass pasture. II - plant nitrogen nutrition. Brazilian Journal of Soil Science 32(1):1601-1607. https://doi.org/10.1590/S010006832008000400024

Coutinho, M.J.F., M.S.S. Carneiro, R.L. Edvan, F.E.M. Santiago and D.R. Albuquerque, 2015. Morphogenic, structural and productive characteristics of buffelgrass under different irrigation shifts. Pesquisa Agropecuária Tropical 45(2):216-224. http://dx.doi.org/10.1590/1983-40632015v4531361

Cunha, E.S. D.S. Martins, G.J.A. Carvalho and J.A.A. Espindola, 2012. Organic fertilization and nutrient content in lemon grass. Biology Journal 9(1):1-5.

Dias-Filho, M.B., 2007. Pasture degradation: processes, causes and recovery strategies. Belém: Author's Edition, 190 p.

Dias-Filho, M.B., 2002. Tolerance to flooding in five Brachiaria brizantha accessions. Pesquisa Agropecuária Brasileira 37(4):439-447, 2002. http://dx.doi.org/10.1590/S0100-204X2002000400003 
Dias-Filho, M.B. and C.J.R. Carvalho, 2000. Physiological and morphological responses of Brachiaria spp to flooding. Pesquisa Agropecuária Brasileira 35(10):1959-1966. http://dx.doi.org/10.1590/S0100-204X2000001000006

Ferreira, D.F. (2011) Sisvar: a computational system of statistical analysis. Science and Agrotechnology 35(6):1039-1042. http://dx.doi.org/10.1590/S1413-70542011000600001

Fischer, A. and S.C. Silva, 2001. The pasture ecosystem and animal production. In: Annual Meeting of The Brazilian Zootecnia Society, 38., 2001, Piracicaba. Proceedings... Piracicaba: Esalq, 733-754p.

Fukao, T. and J. Bailey-Serres, 2004. Plant responses to hypoxia - is survival a balancing act?. Trends in Plant Science 9:449-456. https://doi.org/10.1016/j.tplants.2004.07.005

Jackson, M.B. and W. Armstrong, 2008. Formation of aerenchyma and the processes of plant ventilation in relation to soil flooding and submergence. Plant Biology 1(3):274-287. https://doi.org/10.1111/j.1438-8677.1999.tb00253.x

Kano, T., S. Uozumi, M.C.M. Macedo, J.D.G. Santos Junior, J.G.R. Beretta and M.R. Correa, 1999. Evaluation of four Brachiaria species submitted to water stress. In: Annual Meeting of The Brazilian Zootecnia Society, 36., 1999, Porto Alegre.

Klar, A.E. A. Usberti and D.W. Henderson, 1978. Differential responses of guinea grass populations to drought stress. Crop Science 18(5):853-857.

Kroth, B.E., 2013. Productive and Nutritional Characteristics of Forage Grass in Excess and Water Deficit Conditions. Master thesis in Agricultural Engineering. 64f. Federal University of Mato Grosso, Institute of Agricultural and Technological Sciences, Rondonópolis.

Kroth, B.E., E.M. Bonfim-Silva, T.J.A. Silva, M. Koetz and A.F. Schlichting, 2015. Brachiaria brizantha cultivars under different water availability in Fluvic Neossol. Brazilian Journal of Agricultural and Environmental Engineering 19(5):464-469. http://dx.doi.org/10.1590/1807-1929/agriambi.v19n5p464-469

Liao, C.T. and C.H. Lin, 2001. Physiological adaptation of crop plants to flooding stress. Proceedings of the National Science Council, 25(3):148-157.

Lima, E.V., T.R.B. Silva, R.P. Soratto and C.A.C. Crusciol, 2007. Relationship of chlorophyll meter reading with total N in millet leaf (Panicum miliaceum L.) as a function of nitrogen top dressing. Brazilian Journal of Corn and Sorghum 6(2):149-158.

Loreti, E., V.H. Van and P. Perata, 2016. Plant responses to flooding stress. Current Opinion in Plant Biology 33(1):64-71. http://dx.doi.org/10.1016/j.pbi.2016.06.005

Ludlow, M.M. and T.T. Ng, 1976. Effect of water deficit on carbon dioxide exchange and leaf elongation rate of panicum maximum var. trichoglume. Australian Journal of Plant Physiology 3(3):401-413. https://doi.org/10.1071/PP9760401

Ludlow, M.M. and T.T. Ng, 1977. Leaf elongation rate in Panicum maximum var. trichoglume following removal of water stress. Australian Journal of Plant Physiology 4(2):263-272. https://doi.org/10.1071/PP9770263

Mattos, J.L.S., J.A. Gomide and C.A.M. Huaman, 2005. Growth of Brachiaria species under water deficit in a greenhouse. Brazilian Journal of Zootechnics, 34(3):746-754. https://doi.org/10.1590/S1516-35982005000300005

Neumann, P.M., 1995. The role of wall adjustment in plant resistance to water deficits. Crop Science 35(5):1258-1266. https://doi.org/10.2135/cropsci1995.0011183X003500050002x

Pasin, N.H., B.G. Santos Filho, D.S.B. Santos and V.D.C. Mello, 1991. Performance of bean seeds from plants subjected to water deficit in two growth stages. Pesquisa Agropecuária Brasileira 26:183-192.

Pes, L.Z. and M.H. Arenhardt, 2015. Plant Physiology. Federal University of Santa Maria, Polytechnic College, Rede e-Tec Brasil, 81p.

Rosa, T.A., T. Pedó, E.G. Martinazzo, V.M. Gehling, G.R. Aisenberg, T.Z. Aumonde and F.A. Villela, 2015. Soil waterlogging: effect on the initial growth of oat (Avena sativa L.). Scientia Agraria Paranaensis 14(2):127-131. http://dx.doi.org/10.1818/sap.v14i2.10101

Rosenthal, W.D., G.F. Arkin and P.J. Shouse, 1987. Water deficit effects on tanspiration and leaf growth. Agronomy Journal 79(6):1019-1026.

Salah, H.B.H. and F. Tadieu, 1997. Control of leaf expansion rate of droughted maize plants under floating evaporative demand. Plant Physiology 114(3):893-900. http://dx.doi.org/10.1104/pp.114.3.893

Santos, C.C., E.M. Bonfim-Silva, T.J.A. Silva, T.F.S. Santos and D.S. Matos, 2013. Tropical grasses submitted to water stress. Enciclopédia Biosfera 9(17):1563-1570.

Santos, M.C.S., M.A. Lira, J.N. Tabosa, A.C.L. Mello, M.V.F. Santos, 2011. Behavior of Pennisetum clones submitted to controlled water restriction periods. Archivos Journal of Zootechnics, 60(1):31-39.

Schneider, T., M.A. Rizzardi, A.L. Nunes, M.A. Bianchi, S.P. Brammer and A.P. Rockenbach, 2018. Molecular biology applied to weed science. Revista Brasileira de Herbicidas 17(1): 12-24. https://doi.org/10.7824/rbh.v17i1.523

Silva, A.S., V.A. Laura and L. Jank, 2009. Soil flood tolerance of seven genotypes of Panicum maximum Jacq. Brazilian Archives of Biology and Technology 52(6):1341-1348.

Silva, W.J., O.M. Yamashita, P.C.L. Silva, R.A. Felito, A.M. Rocha, A.C.T. Ferreira, A.C.T., M.A.C. Carvalho, T.L. Parente and S. Caioni, 2017. Breakage of dormancy of P. virgatum seeds. Revista da Universidade Vale do Rio Verde 15(2):830-842.

Sistachs, C.M. and J.J. León, 1987. El caguazo (Paspalum virgatum L.): biological aspects, its control in pastures. Havana: Edica, $57 \mathrm{p}$.

Sousa, C.A.F. and L. Sodek, 2002. Plant metabolic responses to oxygen deficiency. Brazilian Journal of Plant Physiology 14:8394.

Striker, G., F. Mollard, A. Grimoldi, R. Leon and P. Insausti, 2010. Trampling enhances the dominance of graminoids over forbs in flooded grassland mesocosms. Applied Vegetation Science 14(1):95-106. https://doi.org/10.1111/j.1654109X.2010.01093.x 
Suralta, R.R. and A. Yamauchi, 2008. Root growth, aerenchyma development, and oxygen transport in rice genotypes subjected to drought and waterlogging. Environmental and Experimental Botany 64(1):75-82. https://doi.org/10.1016/j.envexpbot.2008.01.004

Taiz, L. and E. Zeiger, 2009. Plant Physiology. Artmed: Porto Alegre. 848p.

Takeshita V., K.F. Mendes, M.H. Inoue and A.C.R. Dias, 2018. Effectiveness of atrazine on populations of capim navalha and selectivity of two varieties of pastagem. Revista Brasileira de Herbicidas 17(3):e594. http://dx.doi.org/10.7824/rbh.v17i3.594

Torres Netto, A., E. Campostrini, J.G. Oliveira and R.E.B. Smith, 2005. Photosynthetic pigments, nitrogen, chlorophyll to fluorescence and SPAD-502 readings in coffee leaves. Scientia Horticulturae 104:199-209. https://doi.org/10.1016/j.scienta.2004.08.013

Turner, N.C., 1997. Further progress in crop water relations. Advances in Agronomy 58(1):293-338. https://doi.org/10.1016/S0065-2113(08)60258-8

Valentim, J.F., E.F. Amaral and A.W.F. Melo, 2000. Current edaphic risk zoning and death potential of Brachiaria brizantha pastures in Acre. Rio Branco: Embrapa Acre. 28 p. (Embrapa Acre. Research Bulletin, 29).

Van Loo, E.N., 1992. Tillering, leag expansion and growth of plants of two cultivar s of perennial ryegrass grown using hydroponics at two water potential. Annals of Botany 70(6):511- 518.

Wright, G.C., R.G. Smith and J.R. McWilliam, 1983. Differences between two grain sorghum genotypes in adaptation to drought stress: I. Crop growth rate and yield response. Australian Journal of Agricultural Research 34(6):615-626.

Yamashita, O.M., 2010. Germinal biology of weed Conyza canadensis L. (Cronquist) and Conyza bonariensis L. (Cronquist). 120f. Thesis (Doctorate in Tropical Agriculture), Federal University of Mato Grosso, Cuiabá, MT.

Yordanov, I., V. Velikova and T. Tsonev, 2003. Plant responses to drought and stress tolerance. Bulgarian Journal of Plant Physiology 2:187-206. 